\title{
THE 'WELLBEING' IN SPITE OF EVERYTHING: SMALL SHARING SPACES WITH FAMILIES OR PEER EDUCATORS DURING THE COVID-19 PANDEMIC
}

Diamare Sara ${ }^{1}, D^{\prime}$ Anna Emilia ${ }^{2}$, Furia Rita ${ }^{3}$, Goretti Malvina ${ }^{4}$, Maglio Rosaria ${ }^{5}$, Salerno Marina ${ }^{6}$, Di Trapani Giovanni',

${ }^{1}$ Psychotherapist Psychologist, professor at Suor Orsola Benincasa University and Dir. UOC Quality and Humanization Asl NA1 Centro.

${ }^{2}$ Bachelor's degree in Psychology at Federico II University

${ }^{3}$ Logistics and Production Management Engineer, GISA Operation Manager in Bologna, Theatre therapist ${ }^{4}$ Bachelor's degree in Cognitive Psychology at Suor Orsola Benincasa University

${ }^{5}$ Sociologist, Mindfulness expert, Voicing trainer and Subject Expert at Suor Orsola Benincasa University

${ }^{6} \mathrm{PhD}$ in Humanities and Technologies at Suor Orsola Benincasa University

${ }^{7}$ Research fellow IRISS CNR, Professor in Economic Statistics, Ph.D in Economics and Business Management at

University of Salerno

KEYWORDS: wellbeing, COVID-19 pandemic, healthy lifestyles, resiliency, teaching, online

\section{ABSTRACT}

During the difficult period caused by the Covid-19 pandemic, a workshop was implemented online, leading a study about the effectiveness of the 'Salotti del BenEssere (C)' model among students and future educators. This course is the result of the collaboration between the Suor Orsola Benincasa University in Naples and ASL Napoli 1 Centro. It's a model of salutogenesis that specifically proposes a multicentre space for the evaluation and spread of healthy lifestyles. Due to the pandemic and the consequent social isolation, the 'keys'to access the main topics for the healthy lifestyle promotion were explored online in order to overcome social isolation; at the beginning of each lesson on the Salotti del BenEssere (C, audio files were provided to guide the students through the experience of each "key": Breathing, Nutrition and Emotions.The lessons were carried out through distance teaching on the online platform called "Google Meet". For evaluation purposes, questionnaires that were originally created in paper format were transferred to the online opensharing platform "Google Forms". The general aim of the evaluation is to establish whether the educational process formulated by the "Salotti del BenEssere ()" has an impact on self-perception in relationships. The specific aim of this study is to verify whether there were differences between the results achieved by the students who were able to experience the face-to-face lessons and those who were forced to attend the lessons online and, if so, to record which ones are significant. We believe that these innovative and digital techniques can become a tool for future educators, especially in emergency situations, to overcome social isolation.

\section{INTRODUCTION}

In this difficult moment of social isolation due to the Covid-19 pandemic, finding innovative methods to enable communication across spatial boundaries is an important aim, especially if we're talking about psychological health and the relationship between educational and care process, which is the focus of the collaboration between UniSOB and ASL Napoli 1 Centro.

To this end, we have implemented a workshop promoting a study about the effectiveness of the "Salotti del BenEssereC" (1) model with students and future educators, who will be able to cary out caring-related activities in the future. This salutogenic model offers a multicentre approach for the evaluation and dissemination of healthy lifestyles. This aforementioned method of health psychology, which has been evaluated by scientific publications, has been used and tested with Suor Orsola Benincasa University's students and future educators since 2016. Many workshops have been activated during these years, along with peer education processes and co- constructing events for the promotion of culture, art and health.

The 'keys' to access the main topics for the healthy lifestyles promotion, which are extremely important especially in this period, were implemented via web to overcome social isolation. Observation/listening exercises, perception and bodily expressions, were all adapted to this new mode; in order to make everything more interactive, audios were registered to help the students during the process.

The concept of salutogenesis (from the Latin "salus" and the Greek "genesis") was developed in the 1970s thanks to the contribution of the sociologist Aaron Antonovsky; it is considered a progressive process of the possible sources of health. Salutogenesis allows each one of us to focus on how to reconnect to our own balance and to the 'wellbeing'.

Furthermore, a fundamental aspect of salutogenesis is to increase the capacity to face the unknown, to bear and deal with conflicts, and to manage one's emotions. Thus, it is also a matter of recognising the limits of one's physical and psychological strength. 
Moreover, health also depends on how we handle everyday obstacles and problems, including emergencies; it also needs to be said that many social illnesses, such as cardiovascular disorders or obesity, are born and develop if there's a mismanagment.

Health is a continuum: being healthy essentially means being consistent with oneself and the community in which one lives. But when the dangerousness of the context adversely affects the population and the individual, resources and skills must be promoted, hence individual and social empowerment. Continued stress resulting from various causes, like the current pandemic situation, can be indeed harmful to the body, to the point of causing further pathogenic situations. However, we can also see in stressful situations an opportunity to face difficulties in a positive way; there are indeed hidden benefits such as rediscovering the importance of social relationships and our own undiscovered talents which are still unexpressed by simply meditating on ourselves and on the depth of relationships with the outside world.

In a critical situation such as the one we are currently experiencing with the spread of the SARS-CoV-2, students and their families have been forced to embrace difficult changes and radically reshape their daily habits, finding themselves living at home, more or less isolated.

To carry on with the lessons about "I salotti del BenEssere(C)" this year has been a real challenge. The previous years were mainly characterised by workshops, implemented with groups of students. Trying to recreate the same physical, mental, emotional entanglement online seemed like something that could be incomplete and definitely not the same as before. But it's exactly on this point that we focused our interest and our reflections. The key word in this case was Interdependence.

Interdependence necessarily implies the ability to listen: from listening to oneself to listening to others, in order to be able to observe without being judgemental, and especially to find new connections and form of relationship with the others.

Paul Watzlawick states with his first axiom that "You can't not communicate", so we communicate by using both verbal and non-verbal language. In this period, as face-to-face interactions are not possible, non-verbal language is sacrificed. Therefore, it's complicated to pay attention to proxemics, i.e. to the discipline that the anthropologist Edward Hall defines as "the study of how man unconsciously structures microspaces - the distances between people while conducting everyday transactions", and which can therefore provide important information on the type of relationship that exists between two people, since interpersonal distance and spatial relationships between people and the environment play a fundamental role in feeling comfortable or uncomfortable in a situation.

Thus, relational distance is closely related to physical distance. In the case of our online lessons, Hall did not foresee the distance, which we could call 'limitless' as it's a virtual distance that belongs to the digital age, so the challenge is to not only provide cognitive but also emotional/experiential content. It was a small step from here to start our journey with audio and video lessons.

In order to transform the lessons' structure from face-to-face to online, we relied on the elements that Goleman identifies in what he calls emotional intelligence, where elements like self-control, perceptiveness, empathy and attention to others play a dominant role.

We also referred to the concept of Resiliency, i.e. the ability of the individual to cope with difficult and/ or stressful situations and to continue to pursue set goals with an attitude of confidence and optimism, turning what appear to be obstacles into opportunities. Therefore, we introduced the concept of Personal and Social Competences. Personal competences involve: Self-awareness, i.e. the knowledge of one's inner states; Self-mastery, as the ability to master one's inner states; Motivation, i.e. the emotional tendencies that drive or facilitate the achievement of goals. Social competences involve Empathy and Social Skills: Empathy, perceived as awareness of the feelings, needs and interests of others; Social skills, involving conflict management, communication and being a catalyst for change.

Some key points for transformation have emerged during the process:

1. Self-awareness, which involves knowing one's inner states.

2. Motivation, which involves knowing the emotional tendencies that drive or facilitate the achievement of goals.

3. Bonding, collaboration and teamwork.

However, the lessons were divided into a theoretical part and a more experiential one; the experiential dimension also took into account the Mindfulness Based Stress Reduction practises created by Jon Kabat Zinn, in order to bring attention to the present moment with an innovative approach aimed at the perception of well-being and emotional modulation, especially in emergency situations, and to experiment and reflect on oneself with curiosity or in a non-judgmental way. We provided audio files at the beginning of each lesson to guide the student's experience. The audio files were related to the following topics: Breathing, Nutrition and Emotions, each lasting for about 10 minutes. We first guided the practice live and shared the experience with the students, then invited each student to use the audio files provided, either in the family or in the group they were sharing their quarantine with. When this was not possible we also suggested to conduct the experience with a peer group via video calls.

During these months, the internet has been the only way of creating links between those who needed nothing more than feeling each other's closeness. And it's through social networks and video calls that isolation has been transformed into digital meetings, with the possibility not only of feeling close to each other, but also of being able to carry out those activities that until then we would never have thought of having to do behind a screen. This includes teaching.

Therefore, if from some points of view distance learning has been seen in a negative way because of its lack of interactions, on the other hand its use has been fundamental in maintaining the routine and fostering a space similar to what we have been used to in schools and universities.

This is exactly what we tried to do in the framework of "Salotti del BenEssere(C)" web-based experience. 
During the weeks, we tried to encourage the interaction between the students, dividing them into small working groups to allow the development of new friendships and knowledge. The meetings held were aimed not only at teaching something new about the aforementioned topics, but also at being as interactive as possible to allow the creation of a different space disconnected from everyday life. In particular, thanks to the students, families and close relatives were also involved in the Salotti del Benessere (C) experience. Although this was a way of sharing the knowledge absorbed during the meetings, it turned out to be a way of forging even stronger bonds by being together in a different way during a difficult period. With the support of the teachers, the students managed to transform their experiences into narratives; their thoughts and reflections have been collected in the virtual pages of a hypertext. Dense in content, but above all dense in experience and life, these narratives have then been creatively revised by a group of psychologists and sociologists to provide a light and aesthetically pleasing restitution of the contents. In other words, the hypertext's pages are full of the reflections shared between teachers and students, but also of the studies, methods and techniques used during the whole experience.

This online product is being printed as a handbook for training open to the caring professions.

Here's the link:

https://docs.google.com/document/d/1jZPsLX6L qWtPw8rsE7FlaGlLH8aNaa O1g6HBzQdp8g/ edit?usp=sharing

\section{METHODS AND MATERIALS}

We would now like to introduce the action-research methodology activated for the Salutogenesis practices, both in-presence and online, to overcome the current social distancing by involving the students' families and/or small virtual communities.

The training method, both live and via web, mostly consists on workshops about the health lifestyle topics and the possibility to share the experience with other people.

Proposing this training to future educators is connected to the opportunity of opening multidisciplinary spaces for health promotion in various contexts, this in order

\begin{tabular}{|c|c|c|}
\hline & Very Low & Very High \\
\hline $\begin{array}{l}\text { PCS (Physical } \\
\text { Component } \\
\text { Summary) }\end{array}$ & $\begin{array}{l}\text { Substantial limitations in self- } \\
\text { care and in physical, social and } \\
\text { personal activities; } \\
\text { significant physical pain; } \\
\text { frequent fatigue; } \\
\text { health rated as poor }\end{array}$ & $\begin{array}{l}\text { No physical limitations, disabilities or } \\
\text { decrease in general well-being; } \\
\text { high vitality } \\
\text { health rated excellent }\end{array}$ \\
\hline $\begin{array}{l}\text { MCS (Mental } \\
\text { Component } \\
\text { Summary) }\end{array}$ & $\begin{array}{l}\text { Frequent psychological } \\
\text { distress; } \\
\text { significant social and personal } \\
\text { impairment due to emotional } \\
\text { problems; } \\
\text { health rated as poor }\end{array}$ & $\begin{array}{l}\text { Frequent positive psychological attitude; } \\
\text { absence of psychological distress and } \\
\text { limitations in social and personal activities } \\
\text { due to emotional problems; } \\
\text { health rated excellent }\end{array}$ \\
\hline
\end{tabular}

Tab 1 to improve the ability of Listening and facilitate the discovery of discomfort and submerged needs, as well as acquiring techniques to support and promote the maintenance of a healthy lifestyle by experiencing first-hand the effectiveness.

Moreover, the Peer Education process activated in the online mode, allowed the students of the previous workshops to be a fundamental part of the course which can be considered as an indicator of the effectiveness of the educational process.

As previously stated, the training was adapted and carried out on the online platfrom Google Meet to allow students to still join the classes despite the social isolation. In addition, this led to the possibility of using another online platform called Google Form to collect datas for our planned questionnaires.

An essential aspect of the 'Salotti del BenEssere(C) method is also its evaluation, for which an integrated qualitative-quantitative model was adopted to verify its effectiveness through a participatory approach.

The evaluation of the course, both in the in-person and online modes, was carried out through a battery of tests, identified by Dr. Diamare and administered by two psychologists, at the beginning and end of the training course.

In particular, the following tests/questionnaires were transferred into Google Form, of which we provide the access link below:

\section{- Healthy Lifestyles Interview}

Elaborated on the notes of the PASSI 2005 project (Progress of Health Authorities for Health in Italy) of the National Institute of Health. The interview aims to investigate the subjects' lifestyles and habits. The items concern in particular diet, sporting activity, the amount of time spent on the $\mathrm{PC} /$ phone, interest and perception regarding physical fitness.

See the following link:

https://forms.gle/whhGanG7KovJxRdH8

- Body Self Awareness (BSA) (Diamare S., Scafuto F., 2018).

It is a self-report test oriented to measure the selfperception of the various body districts and body tensions. Here's the link: https://forms.gle/pbAdhbW4tWNXj1nn6

- Short Form Health Survey (SF12) (Ware, Kosinki \& Keller, 1996)

This is a self-administered instrument for measuring health-related quality of life. This test is the short version of a broader subjective evaluation questionnaire called SF36. The latter version is designed to reconstruct two synthetic indices:

The two indices reflect a combination of mental and physical functions and "wellbeing", different degrees of "disability" on a social and personal level, and "personal evaluation" of health in general.

See link below:

https://forms.gle/WZN91YDKQ7t2PsAx7

\section{Aims}

The general objective of the evaluation is to establish whether the educational process formulated by 


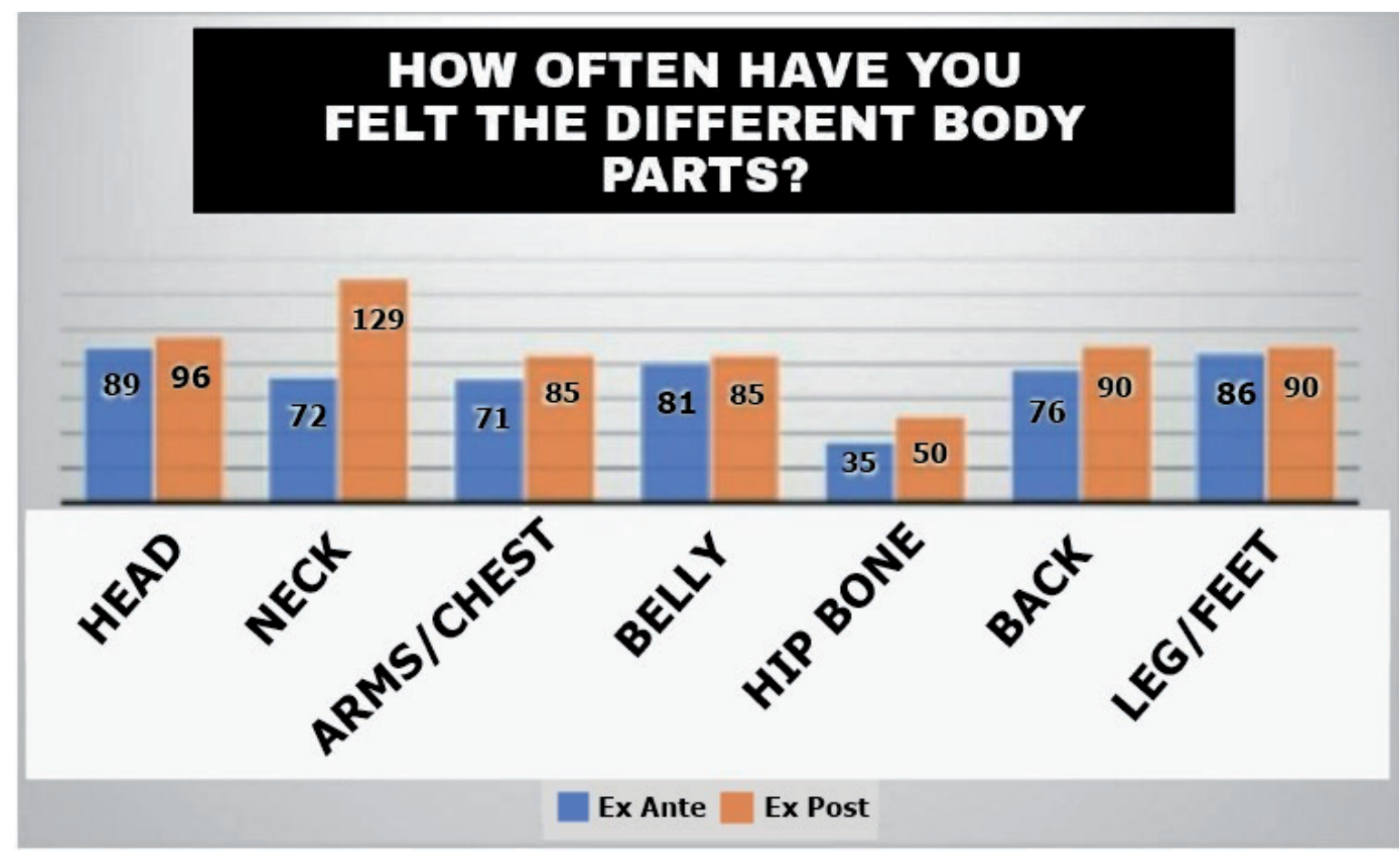

Graph 1

the "Salotti del BenEssere $C$ " has an impact on the perception of self in relationships.

The specific objective of this study is to verify whether there are differences between the results achieved by the learners who experienced the in-presence mode and those who were forced to use the online mode and, if so, to record which ones are significant.

In particular, for a more complete evaluation of the impact on the perception of physical and mental health of the online version, the data emerging from the ex ante/post administration of the SF12 test were compared with a control group that had previously participated in the same workshop in presence.

\section{Results}

The qualitative/quantitative assessment integrated in the "Salotti del BenEssereC" method makes it possible to estimate the demand for health, using monitorable health indicators and the verification of the effectiveness of health promotion actions through a process of empowerment of the participants. It also favours the dissemination of a culture of well-being even in periods of pandemic emergency.

The following analysis was carried out on a sample of 30 students attending the distance learning course (a.y. 2019/2020) aged between 21 and 34 years old.

\section{Body Self Awareness}

Data processing shows that:

There is an overall increase in Self-Perception (Total 510/625). The improvement concerns in general all the body districts investigated, in particular there is a greater perceptive increase for the Neck and the Pelvis. (see Graph 1)

The non-parametric "Wilcoxon Signed Ranks Test" was then used to statistically evaluate the data collected. A comparison of the data collected ex ante and ex post shows that the statistically significant data concerns the following items:

Sig. level $<0.04$

Total: statistically significant difference of 0.034 (Asymp. Sig. (2-tailed)).

Sig. level $<0.05$

\begin{tabular}{|c|c|c|c|c|c|c|c|c|}
\hline & $\begin{array}{l}\text { Head } \\
\text { ExPost - } \\
\text { ExAnte }\end{array}$ & $\begin{array}{l}\text { Neck } \\
\text { ExPost - } \\
\text { ExAnte }\end{array}$ & $\begin{array}{l}\text { Arms } \\
\text { Shoulders } \\
\text { Chest } \\
\text { ExPost - } \\
\text { ExAnte }\end{array}$ & $\begin{array}{l}\text { Bellx } \\
\text { ExPost - } \\
\text { ExAnta }\end{array}$ & $\begin{array}{l}\text { Hip Bone } \\
\text { ExPost- } \\
\text { ExAnte }\end{array}$ & $\begin{array}{l}\text { Back } \\
\text { ExPost- } \\
\text { ExAnte }\end{array}$ & $\begin{array}{l}\text { Legs } \\
\text { Feet } \\
\text { ExPost- } \\
\text { ExAnte }\end{array}$ & $\begin{array}{c}\text { Total } \\
\text { ExPost - ExAnte }\end{array}$ \\
\hline z &,$- 992 b$ & $-1,671 b$ & $-1,076 b$ &,$- 409 b$ & $-1,993 b$ & 1,166 & $-1,163 b$ & $-2,124 b$ \\
\hline $\begin{array}{l}\text { Sian. asint. } \\
\text { (two-tailed) }\end{array}$ & .321 & .095 & ,282 & .682 & .046 & 244 & .245 & .034 \\
\hline
\end{tabular}




\begin{tabular}{|c|c|c|c|c|}
\hline & & $\mathbf{N}$ & Median rank & $\begin{array}{l}\mathrm{R} \text { a n } k \\
\text { sums }\end{array}$ \\
\hline \multirow[t]{4}{*}{ Head Ex Post - Ex Ante } & Negative Ranks & 9a & 7,89 & 71,00 \\
\hline & Positive Ranks & $10 \mathrm{~b}$ & 11,90 & 119,00 \\
\hline & Correlations & $10 \mathrm{c}$ & & \\
\hline & Total & 29 & & \\
\hline \multirow[t]{3}{*}{ Neck Ex Post - Ex Ante } & Negative Ranks & $8 d$ & 9,63 & 77,00 \\
\hline & $\begin{array}{l}\text { Positive Ranks } \\
\text { Correlations }\end{array}$ & $\begin{array}{r}14 \mathrm{e} \\
7 \mathrm{f}\end{array}$ & 12,57 & 176,00 \\
\hline & Total & 29 & & \\
\hline $\begin{array}{l}\text { Arms Shoulders Chest } \\
\text { Ex }\end{array}$ & Negative ranks & $10 \mathrm{~g}$ & 10,30 & 103,00 \\
\hline \multirow[t]{2}{*}{ Post - Ex Ante } & $\begin{array}{l}\text { Positive ranks } \\
\text { Correlations }\end{array}$ & $\begin{array}{r}13 \mathrm{~h} \\
6 \mathrm{i}\end{array}$ & 13,31 & 173,00 \\
\hline & Total & 29 & & \\
\hline \multirow[t]{3}{*}{ Belly Ex Post - Ex Ante } & Negative ranks & $9 \mathbf{j}$ & 11,56 & 104,00 \\
\hline & $\begin{array}{l}\text { Positive ranks } \\
\text { Correlations }\end{array}$ & $\begin{array}{r}12 \mathrm{k} \\
81\end{array}$ & 10,58 & 127,00 \\
\hline & Total & 29 & & \\
\hline \multirow[t]{4}{*}{$\begin{array}{l}\text { Hip Bone Ex Post - Ex } \\
\text { Ante }\end{array}$} & Negative ranks & $7 \mathrm{~m}$ & 6,64 & 46,50 \\
\hline & Positive ranks & $12 n$ & 11,96 & 143,50 \\
\hline & Correlations & 100 & & \\
\hline & Total & 29 & & \\
\hline \multirow[t]{3}{*}{ Back Ex Post - Ex Ante } & Negative ranks & $10 p$ & 12,00 & 120,00 \\
\hline & $\begin{array}{l}\text { Positive ranks } \\
\text { Correlations }\end{array}$ & $\begin{array}{r}15 q \\
4 r\end{array}$ & 13,67 & 205,00 \\
\hline & Total & 29 & & \\
\hline \multicolumn{2}{|c|}{$\begin{array}{l}\text { Legs and feet Ex Post - Ex Ante } \\
\text { Negative ranks }\end{array}$} & $8 s$ & 9,31 & 74,50 \\
\hline \multicolumn{2}{|c|}{$\begin{array}{c}\text { Positive ranks } \\
\text { Correlations }\end{array}$} & $9 u$ & 11,29 & 135,50 \\
\hline & Total & 29 & & \\
\hline \multirow[t]{3}{*}{ Total Ex Post - Ex Ante } & Negative ranks & $11 v$ & 8,36 & 92,00 \\
\hline & $\begin{array}{l}\text { Positive ranks } \\
\text { Correlations }\end{array}$ & $\begin{array}{l}15 w \\
3 x\end{array}$ & 17,27 & 259,00 \\
\hline & Total & 29 & & \\
\hline
\end{tabular}




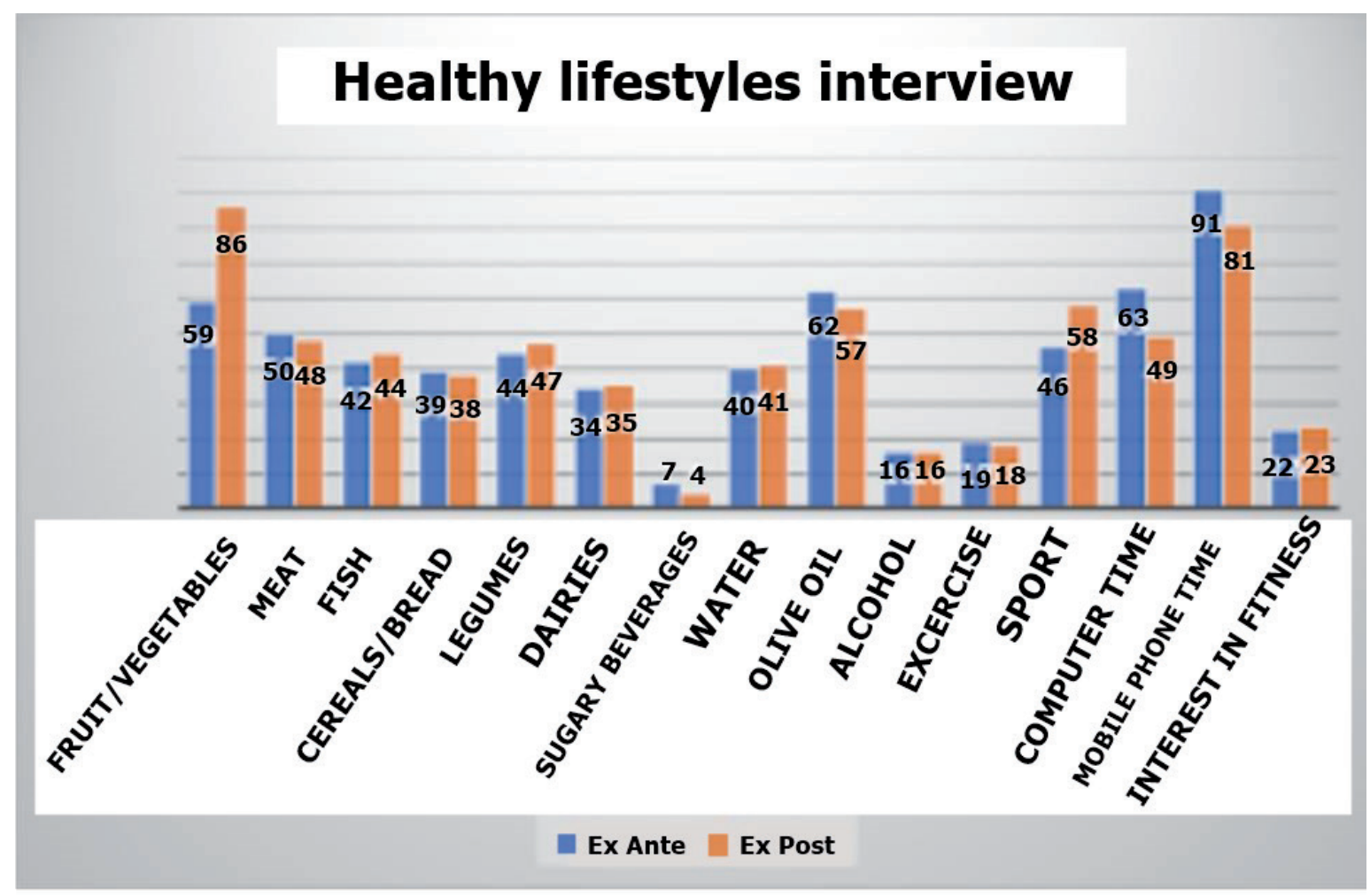

Graph 2

\section{SF12}

600

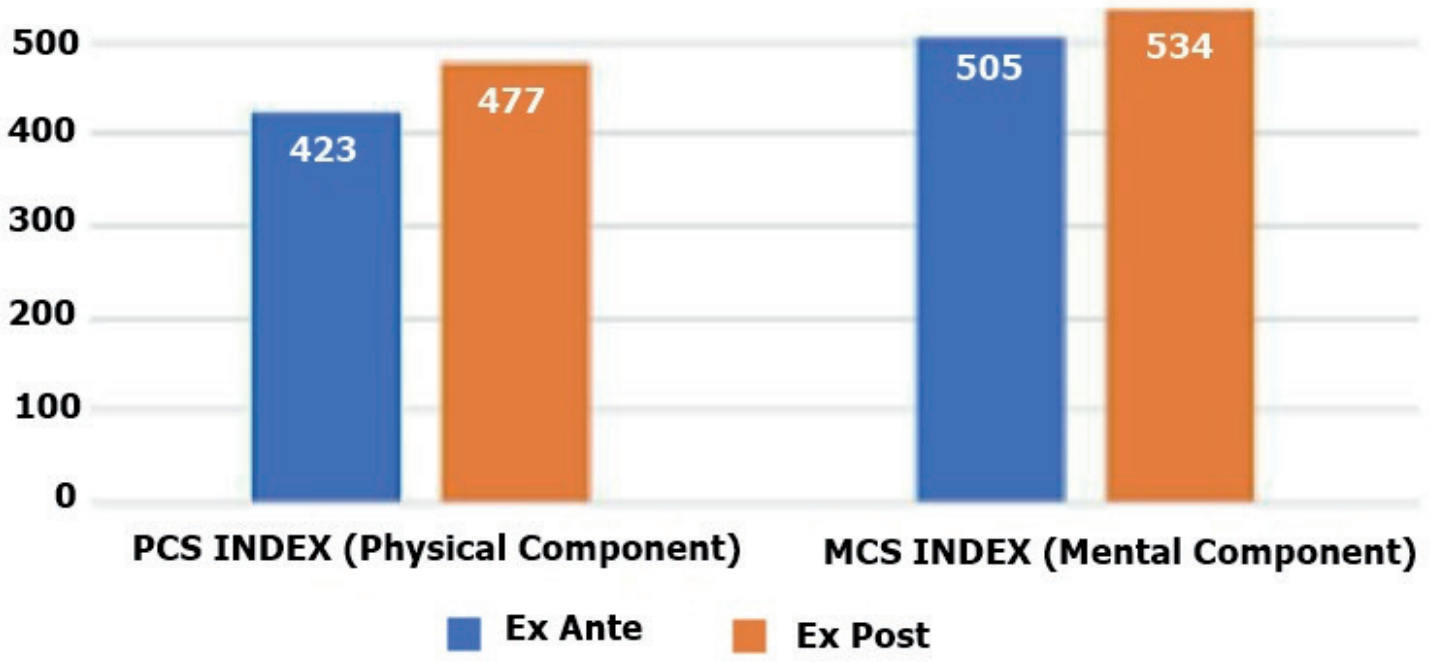

Graph 3

Hip bone: statistically significant difference of 0.046 (Asymp. Sig. (2-tailed)).

As it often happens with psycho-body awareness processes, there was also a slight increase, although not statistically significant, in the perception of body tension (Total 456/473). The process of body awareness, mediated by the use of psycho-corporeal techniques carried out during the specific training, has therefore made it possible to perceive the body with greater accuracy than at the beginning of the training.

\section{Healthy Lifestyles Interview}

From the evaluation conducted on the sample, some improvements emerged regarding diet. In particular (see Graph 2), the portions of fruit consumed during the week increased, while the consumption of sugary/ carbonated drinks per week decreased; the number of hours dedicated to physical and sporting activities also increased, while those spent at the computer during the day decreased. These findings are illustrated by the following graph 2. Although not statistically significant, they are interesting for future research on larger samples of people. 


\begin{tabular}{|l|l|l|l|l|l|}
\hline & $\begin{array}{l}\text { Health Ex } \\
\text { Post - Ex } \\
\text { Ante }\end{array}$ & $\begin{array}{l}\text { Limits Ex } \\
\text { Post - Ex } \\
\text { Ante }\end{array}$ & $\begin{array}{l}\text { Scales Ex } \\
\text { Post - Ex } \\
\text { Ante }\end{array}$ & $\begin{array}{l}\text { Performance } \\
\text { Ex Post - Ex } \\
\text { Ante }\end{array}$ & $\begin{array}{l}\text { Work Ex } \\
\text { Post - Ex } \\
\text { Ante }\end{array}$ \\
\hline$Z$ & $-1,213^{\mathrm{a}}$ & $-2,982^{\mathrm{a}}$ & $-1,000^{\mathrm{a}}$ &,$- 816^{\mathrm{b}}$ & $-1,000^{\mathrm{a}}$ \\
\hline $\begin{array}{l}\text { Sign asint (two- } \\
\text { tailed) }\end{array}$ &, 225 &, 003 &, 317 &, 414 &, 317 \\
\hline
\end{tabular}

a. Based on negative ranks:

b. Based on postive ranks.

\begin{tabular}{|l|l|l|l|l|l|}
\hline & $\begin{array}{l}\text { Emotional } \\
\text { factors Ex } \\
\text { Post - Ex } \\
\text { Ante }\end{array}$ & $\begin{array}{l}\text { Concentration } \\
\text { Ex Post - Ex } \\
\text { Ante }\end{array}$ & $\begin{array}{l}\text { Pain Ex Post } \\
\text { - Ex Ante }\end{array}$ & $\begin{array}{l}\text { Calm Ex } \\
\text { Post - Ex } \\
\text { Ante }\end{array}$ & $\begin{array}{l}\text { Energy Ex } \\
\text { Post - Ex } \\
\text { Ante }\end{array}$ \\
\hline Z & $-1,897^{\mathrm{a}}$ & $-1,633^{\mathrm{a}}$ &,$- 537^{\mathrm{a}}$ &,$- 566^{\mathrm{a}}$ &,$- 845^{\mathrm{a}}$ \\
\hline $\begin{array}{l}\text { Sign asint (tuxo- } \\
\text { tailed) }\end{array}$ &, 058 &, 102 &, 592 &, 572 &, 398 \\
\hline
\end{tabular}

a. Based on negative rankss.

\begin{tabular}{|l|l|l|l|l|}
\hline & $\begin{array}{l}\text { Sadness Ex } \\
\text { Post - Ex Ante }\end{array}$ & $\begin{array}{l}\text { Social Ex Post - } \\
\text { Ex Ante }\end{array}$ & $\begin{array}{l}\text { PCS Ex Post - } \\
\text { Ex Ante }\end{array}$ & $\begin{array}{l}\text { MCS Ex Post - } \\
\text { Ex Ante }\end{array}$ \\
\hline Z & $-1,270^{\mathrm{a}}$ &,$- 145^{\mathrm{a}}$ & $-1,894^{\mathrm{a}}$ & $-1,868^{\mathrm{a}}$ \\
\hline Sign. asint (two-tailed) &, 204 &, 885 &, 058 &, 062 \\
\hline
\end{tabular}

a. Based on negative rankss

Tab. 4 - Wilcoxon signed-rank test statistics

3. Short Form Health Survey (SF 12)

The processing and comparison of ex-ante and ex-post data shows an overall improvement in the perception of quality of life, both in terms of physical and mental health (Graph 3).

And both indices are statistically significant: PCS

Sig. level $<0.06$ statistically significant difference of 0.058 [Asymp. Sig. (2-tailed)].

MCS

sig. level $<0.07$ statistically significant difference of 0.062 [Asymp. Sig. (2-tailed)].

\section{DISCUSSION}

From the qualitative processing of the data above, it emerges that the online lessons, despite the difficulties, have had an effect on the perception of the quality of life and body.

Evaluation of the group in presence:

The same training course but carried out in presence (a.y. 2015/2016), has been used here as a control group, with the participation of n. 52 students (of which 51 were women).

In this second part of the study, we compare the results of the two groups in terms of perception of their own Quality of Life by comparing the results that emerged from the administration of the SF12 test with the same mode of self-assessment. This test was administered to all the participants. 


\begin{tabular}{|c|c|c|c|c|}
\hline \multicolumn{5}{|l|}{ Ranks } \\
\hline & & $\mathbf{N}$ & Mean rank & Rank sums \\
\hline \multirow[t]{4}{*}{ Health Ex Post - Ex Ante } & Negative ranks & $5^{\mathrm{a}}$ & 7,00 & 35,00 \\
\hline & Positive ranks & $9^{b}$ & 7,78 & 70,00 \\
\hline & Correlations & $15^{\mathrm{c}}$ & & \\
\hline & Total & 29 & & \\
\hline \multirow[t]{4}{*}{ Limits Ex Post - Ex Ante } & Negative ranks & $3^{\mathrm{d}}$ & 10,00 & 30,00 \\
\hline & Positive ranks & $16^{\mathrm{e}}$ & 10,00 & 160,00 \\
\hline & Correlations & $10^{\mathrm{f}}$ & & \\
\hline & Total & 29 & & \\
\hline \multirow[t]{4}{*}{ Scales Ex Post - Ex Ante } & Negative ranks & $1^{\mathrm{g}}$ & 2,50 & 2,50 \\
\hline & Positive ranks & $3^{\text {h }}$ & 2,50 & 7,50 \\
\hline & Correlations & $25^{\mathrm{i}}$ & & \\
\hline & Total & 29 & & \\
\hline \multirow[t]{4}{*}{ Performance Ex Post - Ex Ante } & Negative ranks & $4^{j}$ & 3,50 & 14,00 \\
\hline & Positive ranks & $2^{\mathrm{k}}$ & 3,50 & 7,00 \\
\hline & Correlations & $23^{1}$ & & \\
\hline & Total & 29 & & \\
\hline \multirow[t]{4}{*}{ Work Ex Post - Ex Ante } & Negative ranks & $0^{\mathrm{m}}$ & $\mathbf{0 , 0 0}$ & 0,00 \\
\hline & Positive ranks & $1^{\mathrm{n}}$ & 1,00 & 1,00 \\
\hline & Correlations & $28^{\circ}$ & & \\
\hline & Total & 29 & & \\
\hline \multirow[t]{4}{*}{ Emotional factors Ex Post - Ex Ante } & Negative ranks & $2^{\mathrm{p}}$ & $\mathbf{5 , 5 0}$ & 11,00 \\
\hline & Positive ranks & $8^{q}$ & 5,50 & 44,00 \\
\hline & Correlations & $19^{r}$ & & \\
\hline & Total & 29 & & \\
\hline \multirow[t]{4}{*}{ Concentration Ex Post - Ex Ante } & Negative ranks & $\mathbf{1}^{\mathrm{s}}$ & 3,50 & 3,50 \\
\hline & Positive ranks & $\mathbf{5}^{\mathbf{t}}$ & 3,50 & 17,50 \\
\hline & Correlations & $23^{u}$ & & \\
\hline & Total & 29 & & \\
\hline \multirow[t]{4}{*}{ Pain Ex Post - Ex Ante } & Negative ranks & $6^{v}$ & 8,50 & 51,00 \\
\hline & Positive ranks & $9^{w}$ & 7,67 & 69,00 \\
\hline & Correlations & $14^{x}$ & & \\
\hline & Total & 29 & & \\
\hline \multirow[t]{4}{*}{ Calm Ex Post - Ex Ante } & Negative ranks & $5^{y}$ & 8,80 & 44,00 \\
\hline & Positive ranks & $9^{2}$ & 6,78 & 61,00 \\
\hline & Correlations & $15^{\text {aa }}$ & & \\
\hline & Total & 29 & & \\
\hline \multirow[t]{4}{*}{ Energy Ex Post - Ex Ante } & Negative ranks & $7^{\text {ab }}$ & 9,57 & 67,00 \\
\hline & Positive ranks & $11^{\mathrm{ac}}$ & 9,45 & 104,00 \\
\hline & Correlations & $11^{\text {ad }}$ & & \\
\hline & Total & 29 & & \\
\hline Sadness Ex Post - Ex Ante & Negative ranks & $7^{\text {ae }}$ & 12,71 & 89,00 \\
\hline
\end{tabular}




\begin{tabular}{|l|l|l|l|l|}
\hline & Positive ranks & $15^{\text {af }}$ & 10,93 & 164,00 \\
\hline & Correlations & $7^{\text {ag }}$ & & \\
\hline & Total & 29 & & 73,50 \\
\hline Social Ex Post - Ex Ante & Negative ranks & $7^{\text {ah }}$ & 10,50 & 79,50 \\
\hline & Positive ranks & $10^{\text {ai }}$ & 7,95 & \\
\hline & Correlations & $12^{\text {ai }}$ & & 55,00 \\
\hline PCS Ex Post - Ex Ante & Total & 29 & & 155,00 \\
\hline & Negative ranks & $5^{\text {ak }}$ & 11,00 & \\
\hline & Positive ranks & $15^{\text {al }}$ & 10,33 & \\
\hline & Correlations & $9^{\text {am }}$ & & 111,50 \\
\hline MCS Ex Post - Ex Ante & Total & 29 & & 266,50 \\
\hline & Negative ranks & $7^{\text {an }}$ & 15,93 & \\
\hline & Positive ranks & $20^{\text {ao }}$ & 13,33 & \\
\hline & Correlations & $2^{\text {ap }}$ & & \\
\hline & Total & 29 & & \\
\hline
\end{tabular}

a. Health Ex Post $<$ Ex Ante

b. Health Ex Post $>$ Ex Ante

c. Health Ex Post $=$ Ex Ante

d. Limits Ex Post $<$ Ex Ante

e. Limits Ex Post $>$ Ex Ante

f. Limits Ex Post $=$ Ex Ante

g. Scales Ex Post $<$ Ex Ante

h. Scales Ex Post $>$ Ex Ante

i. Scales Ex Post $=$ Ex Ante

j. Performance Ex Post $<$ Ex Ante

k. Performance Ex Post $>$ Ex Ante

1. Performance Ex Post $=$ Ex Ante

m. Work Ex Post $<$ Ex Ante

n. Work Ex Post $>$ Ex Ante

o. Work Ex Post $=$ Ex Ante

p. Emotional factors Ex Post $<$ Ex Ante

q. Emotional factors Ex Post $>$ Ex Ante

r. Emotional factors Ex Post $=$ Ex Ante

s. Concentration Ex Post $<$ Ex Ante

t. Concentration Ex Post $>$ Ex Ante

u. Concentration Ex Post $=$ Ex Ante v. Pain Ex Post $<$ Ex Ante

w. Pain Ex Post $>$ Ex Ante

x. Pain Ex Post $=$ Ex Ante

y. Calm Ex Post $<$ Ex Ante

z. Calm Ex Post $>$ Ex Ante

aa. Calm Ex Post $=$ Ex Ante

ab. Energy Ex Post $<$ Ex Ante

ac. Energy Ex Post $>$ Ex Ante

ad. Energy Ex Post $=$ Ex Ante

ae. Sadness Ex Post $<$ Ex Ante

af. Sadness Ex Post $>$ Ex Ante

ag. Sadness Ex Post $=$ Ex Ante

ah. Social Ex Post $<$ Ex Ante

ai. Social Ex Post $>$ Ex Ante

aj. Social Ex Post $=$ Ex Ante

ak. PCS Ex Post $<$ Ex Ante

al. PCS Ex Post $>$ Ex Ante

am. PCS Ex Post $=$ Ex Ante

an. MCS Ex Post $<$ Ex Ante

ao. MCS Ex Post $>$ Ex Ante

ap. MCS Ex Post $=$ Ex Ante

Tab. 5 - Ranks

By analysing separately the two components of the SF12 test, e.g. physical health (PCS) and mental health (MCS), we wanted to verify whether the two different ways of using the course, in presence and online, had an impact on the two dimensions of Quality of Life related to health (PCS, MCS).

In short, the group that took part in the face-to-face workshops, in line with previous studies (Diamare et. al., 2020) recorded a different impact on the two dimensions of SF12: positive on the physical component (PCS), indifferent on the mental component (MCS), although this impact is not statistically valid.

\section{CONCLUSIONS}

The comparison between the online group and the in-presence group through the analysis of the data emerging from the SF12 test administered ex ante/ post to both groups reveals interesting differences both from the point of view of the stress situation caused by the pandemic emergency affecting the perception of health, and from the point of view of the salutogenic empowerment.

In fact, the comparison between the two groups showed that the values of both dimensions, MCS (Mental component summary) and PCS (Physical component summary), are much lower ex ante in the group of students who participated in the online version of the workshop (a.y. 2019/2020) than the 


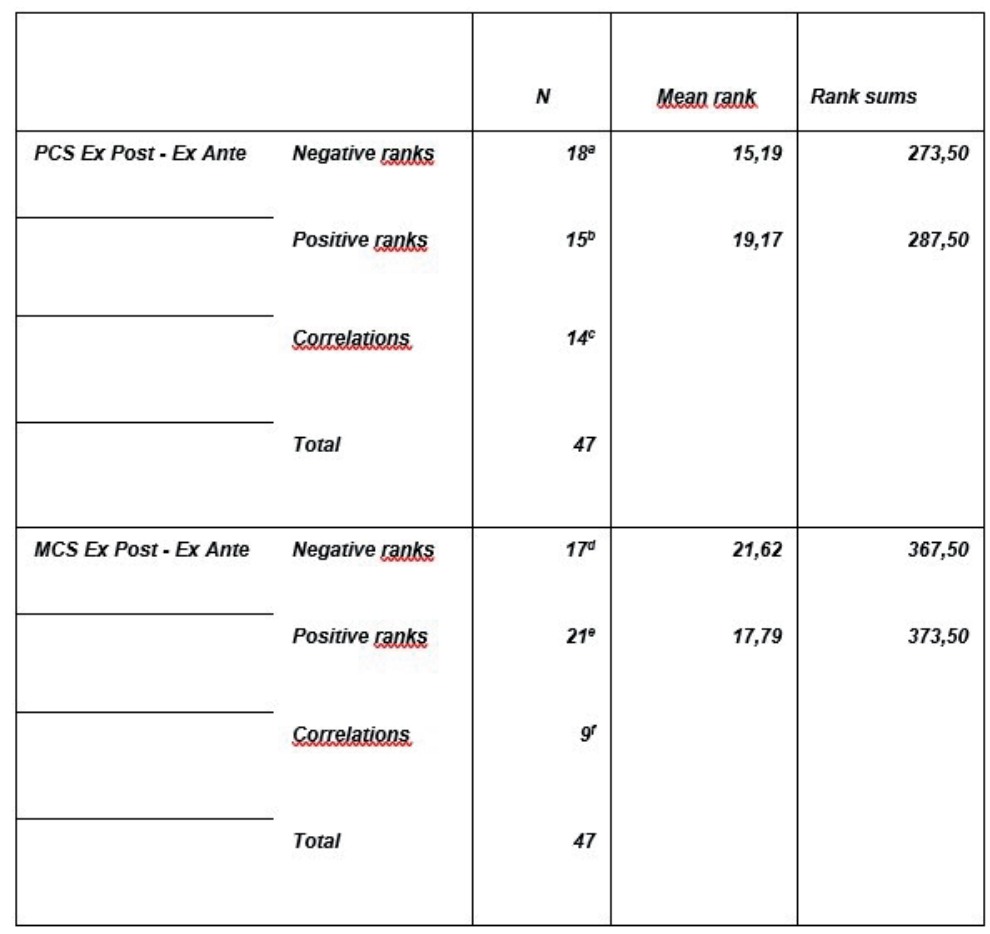

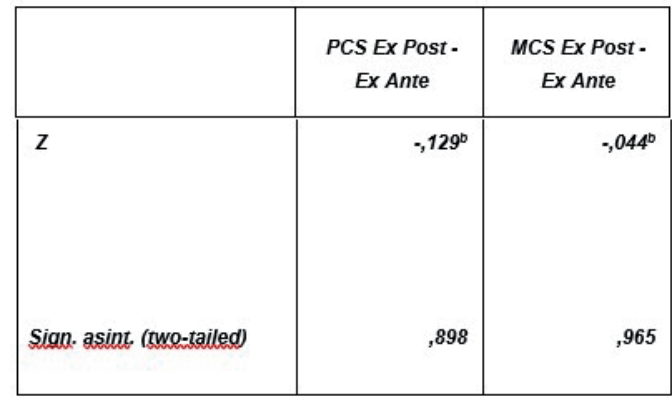

Tab. 7 - Test statistics $^{a}$ - a. Wilcoxon signed-rank test. - b. Based on negative ranks.

Tab. 6 - Ranks - a. PCS Ex Post $<$ Ex Ante - b. PCS Ex Post $>$ Ex Ante - c. PCS Ex Post $=$ Ex Ante - d. MCS Ex Post $<$ Ex Ante - e. MCS Ex Post $>$ Ex Ante - f. MCS Ex Post $=$ Ex Ante values recorded by the administration of the same SF12 test ex ante to the group of students who used the in-person mode. This of course included the effect of the current pandemic situation and recorded the students' perceived feelings of isolation and distress. For the group that attended the lessons in presence, it was found that participation had a positive impact more on the physical component (PCS) than on the mental component (MCS); and in any case this data is not statistically significant. On the other hand, for the online group,there was an overall statistically significant improvement in the perception of the quality of life, both in terms of physical and mental health.

\begin{tabular}{|c|c|c|c|c|}
\hline & & $\mathrm{N}$ & Mean rank & Rank sums \\
\hline \multirow[t]{4}{*}{ Ex Ante - Ex Ante } & Negative ranks & $2^{a}$ & 21,75 & 43,50 \\
\hline & Positive ranks & $25^{\mathrm{b}}$ & 13,38 & 334,50 \\
\hline & Correlations & $2^{\mathrm{c}}$ & & \\
\hline & Total & 29 & & \\
\hline \multirow[t]{4}{*}{$\begin{array}{l}\text { PCS } 16 \text { Ex Post - PCS } 20 \text { Ex } \\
\text { Post }\end{array}$} & Negative ranks & $3^{\mathrm{d}}$ & 3,50 & 10,50 \\
\hline & Positive ranks & $20^{\mathrm{e}}$ & 13,28 & 265,50 \\
\hline & Correlations & $6^{\mathrm{f}}$ & & \\
\hline & Total & 29 & & \\
\hline \multirow[t]{4}{*}{ Ex Ante - Ex Ante } & Negative ranks & $16^{\mathrm{g}}$ & 13,06 & 209,00 \\
\hline & Positive ranks & $8^{\mathrm{h}}$ & 11,38 & 91,00 \\
\hline & Correlations & $5^{i}$ & & \\
\hline & Total & 29 & & \\
\hline
\end{tabular}




\begin{tabular}{|c|c|c|c|c|}
\hline & $\begin{array}{l}\text { Ex Ante } 16- \\
\text { Ex Ante } 20\end{array}$ & $\begin{array}{l}\text { PCS } 16 \text { Ex } \\
\text { Post - PCS } \\
20 \text { Ex Post }\end{array}$ & $\begin{array}{l}\text { Ex Ante } 16- \\
\text { Ex Ante } 20\end{array}$ & $\begin{array}{l}\text { MCS } 16 \text { Ex Post - MCS } \\
20 \text { Ex Post }\end{array}$ \\
\hline Z & $-3,522^{b}$ & $-3,896^{b}$ & $-1,693^{c}$ &,$- 153^{b}$ \\
\hline Sign asint. (two-tailed) &, 000 &, 000 &, 091 & 878 \\
\hline
\end{tabular}

Tab. 9 - Ranks - a. Wilcoxon signed-rank test. - b. Based on negative ranks. - c. Based on positive ranks.

The groups that were concretely engaged in the course with its workshop experiences, both improved their perception of themselves and their physical health, but the online group achieved a significant improvement that also affects the perception of psychological health, which after the course, grows in a process of responsibility, pro-active involvement in the educational relationship, or Resilience to the pandemic situation.

All participants reached particularly deep levels of cognitive and emotional understanding of the other. This, recorded also by the shared observations of the participants, allowed the co-construction of meanings and motivational drives to adopt healthier lifestyles aimed at well-being.
The general aim of the research project associated with the "The relationship with the Other" course is strictly related with the health-promoting nature of the "i Salotti del BenEssere (C)" method, of which the workshop was an expression both in its in-presence version and in its innovative online mode.

We believe that innovative and digital methodologies can find wide applications in the field of health promotion and become a tool for future educators to deal with discomfort related to pernicious lifestyles and for the co-construction of multidisciplinary settings and healthy communities, especially in emergency situations, to overcome social isolation.

Comparison between 2016 and 2020

\section{REFERENCES}

1. Diamare S. (2015), I Salotti del Benessere, Ariello Editori, Napoli.

2. Antonovsky A. (1979), Health, Stress and Coping, San Francisco, Jossey-Bass Publishers.

3. Antonovsky A. (1987), Unraveling The Mystery of Health. How People Manage Stress and Stay Well, San Francisco, Jossey-Bass Publishers.

4. Antonovsky, A. (1996). "The salutogenic model as a theory to guide health promotion”, Health Promotion International, Vol. 11(1), 11-18

5. Gadamer, H. (1994). Dove si nasconde la salute, Raffaello Cortina, Milano.

6. Zucconi A., Howell P. (2015). La promozione della salute. Un approccio globale per il benessere della persona e della società, La Meridiana, Molfetta.

7. Petrillo G. (1996), Psicologia sociale della salute. Salute e malattia come costruzioni sociali, Liguori

8. AA. VV. (2021), "A Cross-Cultural Exploratory Study of Health Behaviors and Wellbeing During COVID-19", Frontiers in Psychology, issue 11

9. Patricia Aguilera-Hermida (2020), "College students' use and acceptance of emergency online learning due to COVID-19", International Journal of Educational Research Open, Volume 1.

10. Ware J Jr., Kosinski M., Keller S. D. (1996), A 12-Item Short-Form Health Survey: construction of scales and preliminary tests of reliability and validity. Med Care.

11. Kabat-Zinn J. (2003)., "Mindfulness-Based Stress Reduction (MBSR)", Constructivism in the Human Sciences, Vol. 8, Fasc. 2.

12. Progetto PASSI: https://www.epicentro.iss.it/passi/en/english

13. Diamare S., Scafuto F. (2018), Body Self Awareness (BSA) Questionnaire

14. Watzlawick P., Beavin J., Jackson D. (2008), "Some Tentative Axioms of Communication" in Book communication theory, Routledge 